Page 213-220. ISBN: 978-602-6 988-75-1

Web Jurnal Online: jurnal.unmuhjember.ac.id

By: Ageng Soeharno

The Language Manners Toward Our Parents

\title{
THE LANGUAGE MANNERS TOWARD OUR PARENTS
}

\author{
Ageng Soeharno \\ Universitas Muhammadiyah Jember \\ mrbigageng@gmail.com
}

\begin{abstract}
Indonesia is a set of islands those are inhabited by many tribes. The set of these islands is called as "Nusantara". Because of inhabited by many tribes, this "Nusantara" has so many cultures, languages, or even manners. Manners is something interested to discuss, because it has unique elements which make it exist in the society. The discussion is setting on the three different manners, they are English, Indonesian and Javanese, because they existed in the society, because they has their own way on interpreting it. The english manners,almost similar to the other manners of the other countries in Europe which has a simple way to express it. The biggest influences is coming from the rules which are used by the government. When the government is a kingdom, it will adjust the manners itself to the rules decided by their own kingdom. It also happens to the government in the form of presidential. There are several things distinguish on applying these manners. All of these happen because of the difersity of the influences of the country. They are because of the systems those are used in the kingdom or presidential countries. All of these rules are made by each country, government or society in order to build a characteristic on their own culture. The building of this culture characteristic participates on building the educational culture for each community. In order to build the this educational culture, it is important to reflect on their daily life of the society.
\end{abstract}

\section{Keywords: Culture, Language, Manners}


Page 213-220. ISBN: 978-602-6 988-75-1

Web Jurnal Online: jurnal.unmuhjember.ac.id

By: Ageng Soeharno

The Language Manners Toward Our Parents

\section{Introduction}

Indonesia is a big country which has a big number of islands and tribes those have their own language which are different among one to others. The Indonesian existence come from the small kingdoms before merging become one new country whose name is Indonesia, finally.

Indonesia is a set of islands those are inhabited by many tribes. That's why the country has another nickname whose name is "Nusantara" or we call it as archipelago. The archipelago streches from Sabang to Merauke.

Because of the diversity of the tribes, this Nusantara has so many cultures and languages, which are also merging into a unition language, which is called as "Bahasa Indonesia" or we call it as Indonesian. Besides, Bahasa Indonesia has a biggest local language as the regional language with the largest users, it is Javanese.

Javanese is a language which is used by them who mostly live Java island in Indonesia. As the language whose formed from the local kingdom in Indonesia, as usual, the language has its own manners. The manners meant here is the level of the language which is used by them who speaks to someone who is more respected.

Herewith, let's discuss them the language manners as discussed above, one by one, from English, Indonesian, and Javanese.

\section{Discussion}

The earliest education begins in our social life. That's why, the social life is the most influential life in our lives. The social life is the life that guides us how to relate others.

The first person we met is our mother. She guided us everything we need to walk through our life.

In term of language, the journey of the human life begins from the time of birth. Firstly, our ability was just crying. We could not do anything except that. That's the first time we studied to talk. We start getting bigger then. Beside crying, we tried to differentiate among our mother and father by listening their voice. That's the first time we studied listening.

Getting bigger, our parents brought us to the lowest level of the school, it was Kindergarten School. It was started when our teacher was teaching us to read something. That's the first time we learned reading. Then, at almost the same time to, it was started when our Kindergarten School teacher was guiding us to draw animals, flowers, and letters. That's the firs time we learned writing.

That's the picture of the educational journey we receive. From this picture we can draw lessons that the language manners was started from the first time we breath.

\section{English}

English is the most important language in the world. As the first international language in the world, English became the language which is most widely used by many countries in the world. 
Page 213-220. ISBN: 978-602-6 988-75-1

Web Jurnal Online: jurnal.unmuhjember.ac.id

By: Ageng Soeharno

The Language Manners Toward Our Parents

English is not only used in politics and economics, but also covers other fields such as social, cultural, and educational.

The foreign speakers of English tend to learn English structurally without having to learn it in terms of culture.

That's why they often use English in a disrespectful manner, or in other words they use English at will. The use of English at will is clearly seen in people who are just learning English and trying to dare to speak to other people who are already good at speaking English. It means that it doesn't apply to the native speaker.

\section{History of English at Glance}

Based on the research of linguists as well as some ancient text sources, English began originally from West Germanic Language, which originated in England. English does not just happen. This language experiences a mixture and mixing of various kinds of language combinations such as those used by Norwegians, Danes, and Anglo Saxons. This period lasted quite a long time, which began around the 6th century until the 10th century.

Initially, Old English was a group of dialects reflect the origins of various AngloSaxon kingdoms in England. In one of these dialects, the West Saxon finally dominates. Then in the original Old English then finally influenced by two waves of invasion.

In 1066, changes began. England at that time was successfully conquered by William the Conquer, or also often known as the Conqueror of Normandy, North France. England, which was under William's control, made this country a great influence in terms of language. Because William himself came from France, he and his troops also helped spread the use of French. So, English was then intensively affected by French and Latin. In fact, research shows that the modern English we use today has less than $50 \%$ of its own originating from French and Latin. Because of the great power of the French state, French was also used as an official language for centuries within the government.

That is why, because the English conquerors were from the kingdom, then this, in part, affected the language of life of the English people. In which, this is inevitably the use of language has to use the royal ordinances. It was marked by the presence of language in manners.

\section{The English Manners}

Our father and mother are our best friends at home. They love and care us everyday, everynight, and everytime. Not only love and obey them at home, but we also have to be polite and taking care for them. Not only to our parents but also to all of our brothers and sisters.

Say "Good morning" every morning to all of the other members of our family, and say "Good night" on going to bed.

We also have to say "Good-by" to our father and mother on leaving home, and at the time school is dismissed we have to go home at once unless we remain on the request of the teacher, and on reaching home let our parents know that we have returned. 
Page 213-220. ISBN: 978-602-6 988-75-1

Web Jurnal Online: jurnal.unmuhjember.ac.id

By: Ageng Soeharno

The Language Manners Toward Our Parents

We have to say "Please" or "If you please" when asking for something as "Give me your hand, please." "Please, may I play with Rahman, Mother?" Answer, "Certainly".

We don't have to pass rudely in front of anyone. If necessary and we have to pass in front of someone, we have to say "Excuse me, please", or "Please, excuse me".

Never quarrel with the member of our family, and we have to speak kindly to servants. And the last is we don't have to interrupting the conversation when the older people are talking, never enter into the conversation unless our elders ask to do so.

\section{Indonesian}

Indonesian was born on October 28, 1928. Where on that date, the youth from all corners of the archipelago gathered and pledged Sumpah Pemuda with the contents:

1. One blood swear, Indonesian homeland

2. One nation, the Indonesian nation, and

3. Speak one language, Indonesian.

With the Sumpah Pemuda, Indonesian was later confirmed as a the national language. Then on August 18th, 1945, Indonesian became the language of the country which is contained in the 1945 Constitution, Chapter number XV, Article number 36.

\section{History of Indonesian Language at Glance}

The history of Indonesian is very closely related to Malay. Since long ago, Malay was a language used as an intermediary or social language. So that the basic Indonesian 1 anguage comes from Malay.

Malay was the language used by Sriwijaya Kingdom. Sriwijaya was a kingdom that was taking place in South Sumatera.

It was started when the Sriwijaya Kingdom was able to conquer the kindoms in the region of South East Asia, and used it as the intermediary language. It was proven by the inscriptions in the Kedukan Bukit in Palembang in the year $683 \mathrm{AD}$. Then the limestone city in West Bangka was dated $686 \mathrm{AD}$ and Karang Brahi in Jambi was dated $688 \mathrm{AD}$.

On the usage in Sriwijaya Kingdom, Malay language has several function those were used in the kingdom, they were:

1. The Cultural Language

It was used as the language on the spread the Buddhism

2. Lingua Franca

It was the language which was connect tribes in the archipelago

3. The Language of Trade

Malay language that does not know the level of speech was the language most used by traders

4. Official Royal Language

Malay language is the official royal language in the Sriwijaya Kingdom.

From all of the informations above, we can draw a conclusion that Malay language is the most influenced language to Indonesian. 
Page 213-220. ISBN: 978-602-6 988-75-1

Web Jurnal Online: jurnal.unmuhjember.ac.id

By: Ageng Soeharno

The Language Manners Toward Our Parents

\section{Islamic Influence}

The history of Indonesian is not only influenced by the existence of Malay language which is the most important influence but also the existence of Islam which characterizes the formation of the next Indonesian language.

Since the entry of Islam into Indonesia, since then Islamic culture has also influenced the cultural diversity in Indonesia. Islamic culture has entered into various aspects of Indonesian people's lives.

As the last religion, Indonesian society initially compared between previous teachings and Islamic teachings.

Within the existence of the Islamic teachings that allowed the local culture to develop, this is what ultimately makes Indonesian people voluntarily embrace this new religion.

At least, the influence of Islam in Indonesia covers 4 fields, as follows:

1. Political field,

Before Islam entering Indonesia, Hindu and Buddhist kingdoms had first developed. At a time when the Hindu and Buddhist kingdoms had begun declining their role, it was the time that Islam took over, and changed it from the royal system to the sultanate system. The sultanate system is the system regulates the control of power in a country.

2. Social field,

On the Hindu and Buddhist period, there were the assertive social levels, which was called Kasta, they are Ksatria, Brahmana, Waisya, and Sudra. But since the coming of Islam, these assertive social levels had been abolished.

3. Religion field,

On the Hindu-Buddhist period, the adherents were taught to worship the gods. but since the Islamic period, the adherents have been taught to worship the only God, it is Allah.

4. Cultural field.

In the process of entering Islam into Indonesia, it was also marked by the entry of Islamic culture into Indonesia. The most influential thing that was mostly influent in this matter was the interference of the "scholars" known as "Wali Songo".

It was them who finally started to do the acculturation from Hindu-Buddhist culture to the Islamic one. The most concrete example in this case is the existence of a puppet story created by Sunan Kalijaga entitled "Jamus Kalimasada".

Jamus means the magic object. Whereas "kalimasada" comes from the word "Kalimat Syahadat" or "The Sentence of The Faith Testimony".

Reviewing from the previous Kalimasada sentence, that the sentence was originated from Sanskrit, which was found in Kakawin Bharatayuddha, which was read as Kalima Hosaddha, where the sentence was originally came from Kali-Maha-Usaddha, which meant "the panacea of Goddess Kali".

Kakawin comes from Sanskrit which means the literary work of a great poet. Kakawin Baratayuddha itself was written during the reign of Maharaja Jayabhaya in $1157 \mathrm{AD}$ or in the 12th century AD, a Maharaja of the Kingdom of Kadiri. 
Page 213-220. ISBN: 978-602-6 988-75-1

Web Jurnal Online: jurnal.unmuhjember.ac.id

By: Ageng Soeharno

The Language Manners Toward Our Parents

This opinion was expressed by Dr. Kuntara Wiryamartana, SJ. From the sentence of the Kalimahosaddha which comes from Sanskrit, which could be seen in a book written during the Hinduism kingdom, then attracting the people who at that time were many Hindus, then Sunan Kalijaga, one of the member of Wali Sanga, composed the story becomes the Kalimasada which was the short of Kalimat Syahadat, which means the Sentence of the Faith Testimony.

All of this was done by Sunan Kalijaga in the context of the "syiar", the converyment of Islam.

\section{THE INDONESIAN MANNERS}

In this case, seeing that the behavior of Indonesians is very much influenced by the strong influence of Islam, then in their daily lives, this influence also affects the speech patterns of Indonesian society in general.

Because it is influenced by the existence of Islam, then some things related to the habits and manners of Indonesian society in general, also influenced by Islam.

For example, in greeting others, someone will say "Assalamu'alaikum". The word "Assalamu'alaikum" is a word that comes from Arabic, which means "may salvation always be poured on you". This greeting means very broad. In that sense, this greeting can be used in many events, whether it is family events, community events, or even state events.

Furthermore, if we find our parents, then the attitude that must be done is to kiss their hands.

\section{The Javanese Manners}

Manners in Javanese society are called uploads or manners. This manners are used as guidelines by the Javanese people in behaving or interacting. Manners contain custom values that apply to certain areas so that ethnic groups will not be the same or valid. Manners are obtained by individuals through a process of interaction within the family or community. Manners that are still run by Javanese people include manners in the use of language, saying goodbye, sitting, eating and drinking, dressing and visiting.

Manners in a family environment such as the use of language in everyday conversation. Javanese people use Javanese to further strengthen relationships between family members. At this time the use of the Javanese language Krama Inggil which is a language used to respect older people is rarely used. Many children use the Ngoko language to their parents or siblings. Many children today do not even recognize him anymore because they have not been taught by their parents since they were young. Many parents prefer teaching Indonesian to Javanese.

As far as I observe, children still obey the advice of parents. Obeying parental advice is a form of respect. However, if ordered to do something, sometimes it is reluctant to run it and even if it is carried out with coercion.

A child if he wants to travel or leave home, in general has been accustomed to say goodbye. Farewell is one form of courtesy. The purpose of saying goodbye is to ask for blessing so that something undesirable does not happen and that parents do not worry 
Page 213-220. ISBN: 978-602-6 988-75-1

Web Jurnal Online: jurnal.unmuhjember.ac.id

By: Ageng Soeharno

The Language Manners Toward Our Parents

about the departure of their children. When saying goodbye is usually accompanied by kissing the hands and cheeks of the parents.

The correct sitting procedure is a polite sitting position. When using a chair, both feet must be under and in a tight position. At this time the sitting position in a family either on a chair or on the floor is done in a relaxed and comfortable position. The sitting position is no longer as formal as in the past. For example when watching TV together or while relaxing.

Manners in eating and drinking which is still run until now is not sounding (tasting) at mealtime. Tasting at meal times is considered rude and disruptive. Besides that, a lot of manners in eating and drinking began to change. When eating and drinking together with friends is mostly done while chatting. Though eating while chatting can result in choking and disrupting breathing. Standing parties are also mushrooming everywhere. This forces the people present to eat and drink in a standing position. Not only at parties but now it has become a habit to eat and drink in a standing position in everyday life.

In ancient times, Javanese people dressed in Javanese and Javanese traditional clothes. Along with the changing times, clothing is produced with a variety of models, distinctive clothing and fingers have begun to be abandoned. Many women today use pants, whereas in the past pants were only for men. Even in clothes, people start to leave politeness. People who dress in mini tight clothes, can be found everywhere.

Visiting is an activity to visit other people's homes, whether they are already known or not. There are guest manners that apply in society. People who visit must pay attention to the right time. Do not visit during recess because it will disrupt the time to have a home. If you have arrived at the destination you should knock on the door and give a greeting, after that express the purpose and purpose of visiting. As a guest who also has to respect the owner of the house, if the dish is served should be eaten so as not to hurt the owner of the house. At present the procedures for visiting are still carried out.

At this time manners have undergone several changes due to the entry of information from various media. The entry of various media both print and electronic is very influential on the use of manners, especially the younger generation. Various information that comes in will affect the order of values prevailing in society. Javanese people tend to imitate the culture that enters through the media in acting and behaving. But for those who can distinguish between good and bad things certainly will not be affected by the entry of these foreign cultures. 
Page 213-220. ISBN: 978-602-6 988-75-1 Web Jurnal Online: jurnal.unmuhjember.ac.id

By: Ageng Soeharno

The Language Manners Toward Our Parents

\section{BIBLIOGRAPHY}

Bennet, Andrew et al.2004.An Introduction to Literature, Criticism and Theory.Harlow: Pearson Education Limited

Devdutt, Pattanaik.2012.JAYA An Illustrated Retelling Of The Mahabharata.New Delhi: Penguin Book India Pvt. Ltd

DuFon, Margaret A.2004.Mari Belajar Sopan Santun Bahasa Indonesia.Manoa: NATIONAL FOREIGN LANGUAGE RESOURCE CENTER University of Hawai'i

Eagleton, Terry.2003.LITERARY THEORY An Introduction.Minneapolis: The University of Minnesota Press

Gow, Alex Murdoch.2013.GOOD MORALS AND GENTLE MANNERS FOR SCHOOL AND FAMILIES.New York: AMERICAN BOOK CO.

Laffan, Michael.2015.Sejarah ISLAM Di Nusantara.Yogyakarta: Penerbit Bentang

Loewenstein, David et al.2002.THE CAMBRIDGE HISTORY OF EARLY MODERN ENGLISH LITERATURE.New York: Cambridge University Press

McVenn, Gertrude E.1919.GOOD MANNERS AND RIGHT CONDUCT.Boston: D. C. Heath \& Co.

Muhammad Yunus, Andi et al.2016.SEJARAH PERKEMBANGAN SASTRA INDONESIA.Makassar: Badan Penerbit Universitas Negeri Makassar

Padmosoekotjo, S.1987.GEGARAN SINAU BASA JAWA.Surabaya: PT Citra Jaya Murti

Post, Peter.2005.ESSENTIAL MANNERS For Couples.New York: The Emily Post Institute. Inc. 